\title{
Proptosis and ovarian masses: extramedullary manifestations of acute myeloid leukaemia
}

\author{
Sebastian Alejandro Mikulic (D) , ${ }^{1}$ Michael Chahin (D) , ${ }^{1}$ Ketav Desai, ${ }^{2}$ \\ Hardik Chhatrala ${ }^{3}$
}

${ }^{1}$ Internal Medicine, University of Florida College of Medicine, Jacksonville, Florida, USA ${ }^{2}$ Pathology and Laboratory Medicine, University of Florida College of Medicine, Jacksonville, Florida, USA ${ }^{3}$ Hematology and Oncology, University of Florida College of Medicine, Jacksonville, Florida, USA

\section{Correspondence to}

Dr Michael Chahin;

michael.chahin@jax.ufl.edu

Accepted 6 April 2021
Check for updates

(c) BMJ Publishing Group Limited 2021. No commercial re-use. See rights and permissions. Published by BMJ.

To cite: Mikulic SA, Chahin M, Desai K, et al. BMJ Case Rep 2021:14:e243045. doi:10.1136/bcr-2021

243045

\section{DESCRIPTION}

A 33-year-old woman presented with back and pelvic pain of 3-week duration. Associated symptoms included diplopia and fatigue. Physical examination revealed proptosis, gum hypertrophy and abdominal tenderness. Her white blood cell count was $61 \times 10^{9} / \mathrm{L}$ with $52 \%$ blasts, haemoglobin $102 \mathrm{~g} / \mathrm{L}$, and platelets $178 \times 10^{9} / \mathrm{L}$. CT of abdomen and pelvis revealed bilateral solid adnexal masses measuring up to $10 \mathrm{~cm}$. MRI of the pelvis showed rectal thickening, the solid ovarian masses and pathologic perineal and inguinal adenopathy. MRI orbits noted thickening and infiltration of orbital muscles (figure 1).

Her bone marrow revealed 90\% involvement by acute myeloid leukaemia (AML) with monocytic differentiation (figure 2).

Biopsy of inguinal lymph node was also consistent with AML. Ovarian masses, inguinal lymph, nodes rectal thickening and orbital muscle infiltration were deemed to be extramedullary manifestations of AML. The patient received induction chemotherapy with cytarabine and daunorubicin with resolution of proptosis and clearance of leukaemic blasts in peripheral smear in 2 days. A follow-up CT of the abdomen and pelvis revealed a decrease in size of the ovarian masses.

AML is a haematopoietic neoplasm that results in clonal proliferation of myeloid precursors. ${ }^{1}$ These cells proliferate with a reduced capacity to differentiate and replace normal bone marrow elements causing pancytopenia. ${ }^{2}$ AML is the most common adult acute leukaemia with median age of diagnosis between 62 and 71 years. ${ }^{1}$ The clinical presentation

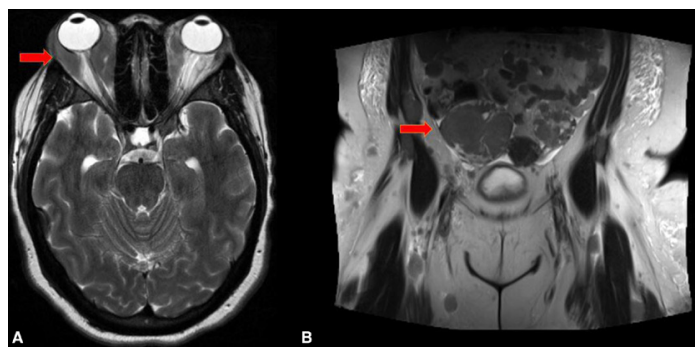

Figure 1 (A) T2 axial MRI orbits showing severe masslike thickening of bilateral extraocular muscles, most severely involving the right medial and lateral rectus muscles, and left medial rectus muscle. (B) T2 coronal view pelvis MRI showing bilateral ovarian masses. The largest on the right measures $>10 \mathrm{~cm}$. Multiple soft tissues and intramuscular masses, and inguinal lymphadenopathy are also present.

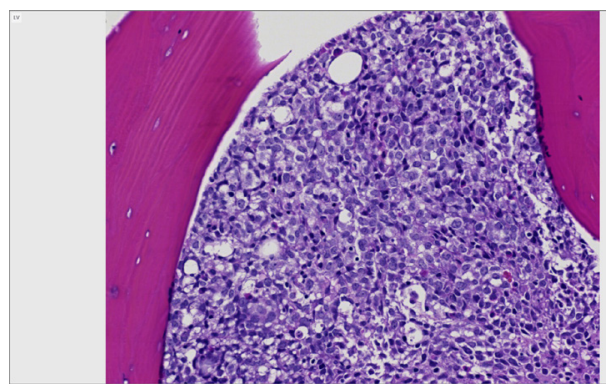

Figure 2 Bone marrow biopsy, H\&E stain, revealing $>90 \%$ involvement by blasts.

usually involves the complications related to pancytopenia and includes weakness, fatigability, infections and haemorrhagic findings such as gingival bleeding, ecchymosis, epistaxis or menorrhagia. ${ }^{2}$ Patients with extramedullary disease (EMD) may also have symptoms related to organ dysfunction due to tumour involvement.

EMD can occur in the presence or absence of bone marrow involvement. The two predominant forms of EMD are myeloid sarcoma (MS) and leukaemia cutis. Leukaemia cutis describes leukaemic invasion of the integument, which often results in subcutaneous nodules. MS, which was present in this patient, most commonly involves bone, periosteum, soft tissues and lymph nodes. ${ }^{4}$ Rarely, with data being limited to case series, ocular and ovarian disease involvement by MS has been reported. The present case is unique from these due to clinical AML involvement of the multiple sites including the ovaries, rectum, gingiva and ocular muscles. ${ }^{56}$

MS involves 2.5\%-9.1\% of patients with AML and its diagnosis requires a high index of suspicion. Even in patients with an established diagnosis of AML, a core biopsy should be considered unless obtaining a tissue sample would be too high risk. Up to $27 \%$ of patients with MS will have isolated tumours. ${ }^{3}$ The present patient had initially been referred for evaluation of ovarian masses and pelvic lymphadenopathy and the diagnosis was only made with the constellation of symptoms and leukaemic blasts on peripheral smear.

Initial treatment of EMD, including isolated disease without bone marrow involvement, involves systemic induction chemotherapy. Local therapy with radiation, surgery or both can be considered for palliation of symptoms from mass effect such as nerve compression. However, this must be in 
conjunction with systemic chemotherapy as nearly all cases of even isolated MS progress to systemic disease. ${ }^{37}$

EMD such as MS can have a variety of presentations, depending on the tissues and organs involved, and requires a high index of suspicion for diagnosis.

\section{Learning points}

- Extramedullary acute myeloid leukaemia (AML), such as myeloid sarcoma, can have a variety of presenting symptoms depending on which organs and tissues are involved.

- The mainstay of treatment of extramedullary AML is systemic chemotherapy. Even isolated extramedullary disease has an extremely high rate of progression to systemic disease when treated with surgery or radiotherapy alone.

Contributors SAM and MC wrote the manuscript and prepared the radiology images. HC edited the manuscript. DK provided the pathology slides and descriptions. All authors were involved in this patient's care.

Funding The authors have not declared a specific grant for this research from any funding agency in the public, commercial or not-for-profit sectors.
Competing interests None declared.

Patient consent for publication Obtained.

Provenance and peer review Not commissioned; externally peer reviewed.

\section{ORCID iDs}

Sebastian Alejandro Mikulic http://orcid.org/0000-0003-4518-2584

Michael Chahin http://orcid.org/0000-0001-9371-0252

\section{REFERENCES}

1 Shallis RM, Wang R, Davidoff A, et al. Epidemiology of acute myeloid leukemia: recent progress and enduring challenges. Blood Rev 2019;36:70-87.

2 Kulsoom B, Shamsi TS, Ahmed N, et al. Clinical presentation of acute myeloid leukaemia - A decade-long institutional follow-up. J Pak Med Assoc 2017;67:1837-42.

3 Almond LM, Charalampakis M, Ford SJ, et al. Myeloid sarcoma: presentation, diagnosis, and treatment. Clin Lymphoma Myeloma Leuk 2017;17:263-7.

4 Bakst RL, Tallman MS, Douer D, et al. How I treat extramedullary acute myeloid leukemia. Blood 2011;118:3785-93.

5 Ohanian M, Pemmaraju N, Rozovski U, et al. Ocular extramedullary myeloid leukaemia. Br J Haematol 2018;180:738-40.

6 Kahn RM, Gordhandas S, Chapman-Davis E, et al. Acute myeloid leukemia presenting as myeloid sarcoma with a predisposition to the gynecologic tract. Case Rep Oncol Med 2019;2019:1-5.

7 National Comprehensive Cancer Network. Acute myeloid leukemia (version 3), 2021. Available: https://www.nccn.org/professionals/physician_gls/pdf/aml.pdf [Accessed 10 Mar 2021].

Copyright 2021 BMJ Publishing Group. All rights reserved. For permission to reuse any of this content visit

https://www.bmj.com/company/products-services/rights-and-licensing/permissions/

BMJ Case Report Fellows may re-use this article for personal use and teaching without any further permission.

Become a Fellow of BMJ Case Reports today and you can:

- Submit as many cases as you like

- Enjoy fast sympathetic peer review and rapid publication of accepted articles

- Access all the published articles

- Re-use any of the published material for personal use and teaching without further permission

\section{Customer Service}

If you have any further queries about your subscription, please contact our customer services team on +44 (0) 2071111105 or via email at support@bmj.com.

Visit casereports.bmj.com for more articles like this and to become a Fellow 